УДК 659.4

\title{
Pushkin and the Doctrine of Stalinism
}

\author{
Anatolii S. Il'in* \\ Krasnoyarsk State Agrarian University \\ 90 Mira, Krasnoyarsk, 660049, Russia
}

Received 16.06.2014, received in revised form 17.07.2014, accepted 31.08.2014

There is an opinion that public relations were formed in the USA in the 1930-s and appeared in Russia only in the 1990-s, along with market economy and democracy. This opinion is not completely true. Indeed, public relations as art and science were formed in the USA. However, communication between the authorities and public (government relations) is traditionally considered to be the communicative function of any state body. A public event or a campaign is often used as a message conveyed through a communication channel.

In the 1930-s in the USSR Joseph Stalin was building his regime by repressions, accusing his opponents of political crimes. But his regime needed a more solid reason. That is why Stalin ideologists used the centennial anniversary of the death of Alexander Pushkin: during the commemoration campaign, the doctrine of world revolution was replaced with the doctrine of building socialism in the only country which served as the ideological foundation of the Red Empire.

Keywords: public relations, communications, A.S. Pushkin, ideology doctrine.

Research area: History.

\section{Monument}

Russian authorities persecuted the poet while he was alive and greatly honoured him three times after his death. Vissarion Belinsky and Apollon Grigoryev struggled for his recognition as a national genius. In 1860, the Tsar's government allowed the public to erect a bronze monument in the poet's memory in the centre of Moscow, though refusing to finance it. Later, activists started to collect voluntary donations all around the country.

Ten years later, the highest authorities approved the monument creation committee. The committee organized three creative project contests. In 1875 A.A. Opekushin won the contest; the work on the monument lasted for five more years.

The monument opening was held on June 6, 1880. Pushkin committee organized a public meeting in the hall of Moscow City Duma. The meeting was attended by the poet's relatives, aristocrats, high officials and famous citizens. Fyodor Dostoyevsky, Ivan Turgenev, Ivan Aksakov, renowned historian Vasily Klyuchevsky and others made considerate speeches at the ceremony. Iakov Polonsky, Apollon Maykov and Alexei Pleshcheyev recited their poems.

A famous litterateur M.N. Katkov reminded that the monument to national saviour leaders

(C) Siberian Federal University. All rights reserved

* Corresponding author E-mail address: a_ilyn@mail.ru 
of the country, Minin and Pozharsky, had been standing lonely at the time. Pushkin did not happen to save his country from enemies, but he possessed the God's gift to grace his people with beauty, glory and stature. His inspirations produced faith in the mission of Russian people. Belonging to Russian party, he was a victim of intrigues ${ }^{1}$.

The centennial of Pushkin's birthday was celebrated on June 6,1899 . But the celebrations were not nation-wide. Answering the plead on opening a new school named after Pushkin, the speakers of the City Duma stated: "Considering Pushkin's lack of contribution to Serpukhov, the request of the gymnasium principal shall be declined". The decision of the Administration of the Queen Ekaterina Railroad considering the suggestion of the workers to provide financial support to the commemoration was also typical: "Pushkin had never served in the Ministry of Transport and it is the task of writers, not railroad agents, to honour him in any way"2

\section{Death commemoration}

The most well-known anniversary was the centennial of the poet's death in 1937. Pushkin Committee was formed to manage the campaign, with branches in provincial regions. The chairman of the Municipal Executive Committee (Ispolkom) N.N. Balakhonov was in charge of the Krasnoyarsk Region Pushkin Committee. Its members planned to establish a scholarship in the name of Pushkin in Minusinsk Pedagogical Technical School, to redecorate Pushkin Drama Theatre, to create busts and bas-reliefs of the genius poet and to establish Pushkin Street in the Worker's Settlement known as the Third International ${ }^{3}$.

The authorities ordered a state publishing house to publish some works by the commemorated poet: 15 thousand copies of "The Captain's Daughter", the same number of his fairy tales' collections, though limiting the number of "Boris Godunov" to 5 thousand copies ${ }^{4}$.

As the mournful date was coming, the Krasnoyarsk party elite, intensely observing the court trial of Pyatakov-Radek-Smirnov, grew cold to the memorial campaign. In January 1937, the activists of Pushkin Committee requested the Region Committee (Kraikom) to fund 50 lectors. But instead of giving money, the Kraikom members demanded a detailed budget calculation ${ }^{5}$.

Meanwhile, cultural workers had already gone to the province. In early February the Organizational Bureau team of the Union of Writers visited Kansk District. They held a literary evening for stakhanovites, shock workers and party activists in the city theatre. After the report, the actors performed some scenes from "The Miserly Knight" and "Evgeny Onegin"6.

Khakas Oblast Committee sent 19 lecturers to rural areas, including 11 Khakas nationals. They spoke of Pushkin in Khakas settlements in their mother tongue. They were followed by the actors of Oblast National Theatre, putting the fairy tales by Pushkin on stage. The greatest success was "The Tale of the Fisherman and the Fish"?.

Teachers took active participation in the campaign. The teaching staff and the students of Krasnoyarsk School No.7 created a so-called Pushkin Corner, which consisted of newspaper cuts, illustrations and their own drawings. The students decorated their exhibition with bouquets of autumn leafs. The school was enthusiastically preparing for a concert and a masquerade.

Students from the rural areas of Minusinsk district made an album with portraits of Pushkin and illustrations to his works. Apart from that, they rehearsed some scenes from "The Miserly Knight" and "Boris Godunov".

A $6^{\text {th }}$ grader of school №35 named Sevastianov even told a journalist that he could 
remember his lessons better if he had read some Pushkin before ${ }^{8}$.

Many young workers admired Pushkin's works. Stakhanovites of Spartak factory, Taisia Kobleva and Maria Il'nitskaia, read some newspaper articles about Pushkin aloud to the workers during lunch breaks. However, the listeners were more attracted to his fiction books. The comrades read aloud "The Shot", "The Blizzard" and finished "The Stationmaster".

The Red Army did not remain uninvolved as well. The library of $\mathrm{N}$ rifle unit kept around 50 books by Pushkin, read to tatters. Amateur performance supervisor lieutenant Klebanov prepared the table of events. According to it, the Red Army soldier Khnyrev gave a lecture on works by Pushkin and soldier Kozlov, having read "Evgeny Onegin" twice, recited some of its verses from the stage ${ }^{10}$.

On the eve of the anniversary, February $9^{\text {th }}$, the Central Executive Committee of the USSR adopted a special resolution. The government decided to name the State Museum of Fine Arts, Leningrad Academic Theatre, many streets, squares and cities after Pushkin ${ }^{11}$.

On February $10^{\text {th }}$ people of Krasnoyarsk started to commemorate the anniversary of the poet's death earlier than people in Moscow. The ceremonial meeting took place in the hall of Pushkin Theatre. It was opened by the Chairman of the Pushkin Committee N.N. Balakhonov. The board of the Presidium consisted of 43 people. There were local communist leaders among them: the First Secretary of Region Committee Pavel Akulinushkin, the Second Secretary Semion Goliudov, the chairman of the Region Executive Committee Iosif Reshchikov, Party Censor Khavkin, the Secretary of Municipal Committee Maxim Stepanov, and the Head of People's Commissariat for Internal Affairs (NKVD) Administration Ans Zalpeter. Proud scientists and stakhanovites stood behind their back.

G. Grigoriev gave an almost two-hours' report on the life of the poet. He richly cited his genius verses but finished the speech with a loud slogan "Stalin is our sun". Everybody sprang to their feet and gave an ovation in the honour of the "Kremlin highlander".

At the end of the meeting a young poet Konstantin Lisovsky recited his poem "To Pushkin", which was warmly welcomed by the listeners. After the intermission the visitors watched the performance of "Boris Godunov"12.

On the same day in Moscow a meeting on Pushkin square gathered almost 200 thousand people. In the evening the fancy dressed crowd filled the hall of the Bolshoi Theatre. There were grandchildren and great-grandchildren of the poet and the Finnish Minister of Foreign Affairs. With great admiration they gazed at the velvet ribbons with golden letters of Pushkin's verses, decorated with artificial flowers.

The royal box was occupied by: Stalin, Molotov, Kaganovich, Ordzhonikidze, Andreev, Mikoyan, Chubar, Petrovsky, Ezhov, Dimitrov, Khrushchev, Kosarev, Antipov, Bulganin, Filatov and Shkiryatov. The seats of the Presidium were taken by members of All-Union Pushkin Committee: Bubnov, Akulov, Kiselev, Serafimovich, Demyan Bedny, Tikhonov, Orlov, Luppol, Bezymensky, Gladkov, Lakhuti, Tabidze and others. Somehow Voroshilov, Zhdanov and Mezhlauk were on both panels.

The Chairman of the Committee gave a short speech and the ceremonial session was opened to the accompaniment of the music of International. Then scientists, playwrights, writers and poets praised the works of Pushkin and thanked Stalin for the happy life he gave to the Soviet people. The session was closed with the national anthem.

The big-city stars were shining at the concert. The Bolshoi Theatre Orchestra replaced the State 
Symphonic Orchestra of the USSR followed by soloists of the Red Banner Ensemble of Song and Dance of the Red Army. The audience burst into exalted applause ${ }^{13}$.

The world showed great response to Pushkin anniversary. The Times published a big article on Pushkin. Turkish newspapers published articles on Pushkin, as well as extracts of his works. The City Hall of Paris named one of its streets after Pushkin ${ }^{14}$.

The people of all the five continents honoured the poet. 166 Pushkin committees organized celebrations in 170 cities of Europe, 28 cities of America, 4 cities of Australia, 8 countries and 14 cities of Asia, in 3 countries and 5 cities of Africa. In total, Pushkin anniversary was celebrated by 42 countries and 231 cities $^{15}$.

At the same time, few of the Soviet organizers survived the "Great cleansing". A week after the meeting Sergo Ordzhonikidze died. 13 days later, the notorious February-March Plenum of the Central Committee opened, with 70 per cent of its participants dying shortly afterwards. Then Stalin's "oprichniks" rushed to ravage the administration personnel in the province. In Krasnoyarsk they repressed not only the top administrators of Krasnoyarsk Region, but also a talented poet Konstantin Lesovsky.

\section{Imperial Style}

The anniversary speeches and newspaper articles voiced the first sovereign overtones that had little resemblance to the first romantic songs of the world revolution begetters.

The Chairman of the All-union Committee Bubnov gave a speech execrating the reactionary Katkov, Dostoyevsky and liberal Turgenev. He announced Pushkin a political poet, who crushed the rulers, aristocratic plebeians, excellent bigots, peons and ignoramuses. According to him, the genius was a friend to Decembrists and strived to establish realism in constant struggle.
It was not a coincidence that the editorial of "The Pravda" savoured the recollections of P. Dolgorukov of tempered in an argument Pushkin calling all officials thieves and scoundrels, saying all generals were beasts longing to hang all Russian nobility in a tree ${ }^{16}$.

That was why Bubnov confidently claimed that Pushkin belonged to those who built, fought and gained under the great banner of MarxEngels-Lenin-Stalin. In its turn, the scale of Pushkin commemorations served as a sign of flourishing Soviet culture that was maturing in the age of the great Stalin's Constitution ${ }^{17}$.

Right after that, the Director of the World Literature Institute explained why everybody was so happy on the anniversary of poet's death. He stated that the commemoration of Pushkin was the celebration of Lenin-Stalin national politics, as Stalin returned Pushkin to the people $^{18}$.

Another editorial of the "Pravda" clearly stated that Russian people broke their way to freedom and happiness, thereby enjoying the love and respect of all the people that inhabit our vast motherland. That is why Leninism was the pinnacle of Russian culture. It nourished the cultures of other peoples destined to get assimilated or go extinct. Besides, Russian had become the language of the world revolution ${ }^{19}$.

Whereupon, every national culture flourishes, when it freely absorbs the life blood of other peoples' cultures. Pushkin was not an exception. Shamefully, the poet had never been abroad, though at the elite school where he studied he was taught to appreciate the ancient and European cultures. In his adolescence, the father of Russian literary language wrote plenty of French poems imitating his favourite poets.

State ideologists carefully blew up the questionable anniversary commemoration to finish the creation of Stalinism doctrine. People 
were thoroughly explained that Leninism was the heir to all Russian culture and Stalin, who loved everything Russian, had inherited it completely. Accompanied by this, Stalin finished off the remains of left and right opposition, held demonstrative elections in the Supreme Soviet and drove beheaded nations to camp barracks of military socialism.

By the way, apart from other ceremonial events, the citizens of Leningrad placed a memorial stone on the place of Pushkin's tragic duel. It was quite symbolical that the organizers were not ashamed to make it of somebody else's gravestone, stolen from a St. Petersburg cemetery.

Propaganda machine quickly distributed the resurrected "national spirit" around the country. Back in June, 1937 Matvey Shkiryatov constantly floundered to Slavophilism at the bashing Plenum of the Krasnoyarsk Region Committee. He admired the wit and cunningness of a Russian peasant and demanded a special approach to the rural life. Stalin's legate claimed that "a peasant instantly feels the way he is treated and learns what kind of fish a non-resident manager is. This was the nation that undertook the revolution and the grand deed commanded by the party of Lenin-Stalin".

He was echoed by a former St. Petersburg proletarian Sergei Sobolev, who came to replace the arrested administrators of the Krasnoyarsk Region Committee. He reminded listeners of the familiar picture in which "the scrubby executive yells at the elderly worker of kolkhoz, threatening to fine him. The peasant silently grins, as everybody can administrate like this. Kolkhoz workers should urgently be raised as owners"20.

The initiated administrators were not surprised by this admired gazing at the Russian peasant "a la Russe". Some years later the Communists, quietly converted to Orthodox Christianity and stopped at the verge of Monarchy.
Stalin used to say that Russian nation had always been a Tsar Nation.

\section{Entertainment industry}

At nights the citizens wanted to watch something. December, 1936, the Pushkin Drama Theater showed shows "The Glory" and "Princess Turandot" which were daily viewed by 600-700 people. Movies "Song of Happiness", "Happy Life" and "Pilots" played at Sovkino cinema were visited by 912 people.

The citizens of Krasnoyarsk more eagerly visited "Rot-Front" cinema which showed "Natalka-Poltavka" and "Party Card". On December 24, 1936 the performances were watched by 2021 people. At "Yung-Sturm" cinema, 877 viewers heartily laughed at the characters of "The Merry Fellows" and "Once Upon a Time in Summer". The highest visitor rate was held by the State Circus, constantly having all the 1000 seats occupied ${ }^{21}$.

By March 1937 the cinema programs had significantly reduced. "Rot-Front" screened only one fiction documentary film called "The Report of Comrade I.V. Stalin on the Project of USSR Constitution at the Eighth Extraordinary All-Union Soviet Summit".

Journalist Stakkatov wrote: "It is a wonderful, unforgettable film of the greatest historic event. It is a valuable contribution into Soviet cinematography. You leave the cinema greatly inspired, with love to the friend and leader, the great Stalin". However a strange inscription sneaked into the poster, saying that the session could not be left before its end ${ }^{22}$. Most likely, the notice was addressed to the irresponsible viewers who made attempts to escape from the dark cinema hall.

In 16 days the state film was watched by 30 thousand people. The viewers were promptly supplied by the Party team. The Municipal Committee toughly scolded the party organizers 
of the Machine Repair Plant and China Factory who could not drive the workers to the collective movie session ${ }^{23}$.

$* * * * *$

This way, Stalin's ideologists filled the official communication channels with messages about Pushkin. But the context of this message bore a new ideological doctrine.
The Russian Empire had the formula of "Orthodoxy, Autocracy, and Nationality". In 1917 the Bolsheviks replaced it with "Military Communism, World Revolution and Internationalism". During the anniversary events of 1937 a new "Communism-StalinismSoviet people" formula was created, and it was maintained until the Khrushchev Communism Construction Program.

\footnotetext{
Katkov, M.N. (1880). Pushkin's Merit. Russkiy Vestnik, 6, pp. 403-409.

The Dream of the Great Poet Comes True (1937). Pravda, February, 11.

Krasnoyarsk Region State Archive. fund 26, list 1, file 204, page 221.

Krasnoyarsk Region State Archive. fund 26, list 1, file 204, page 157.

Krasnoyarsk Region State Archive. fund 26, list 1, file 437, page 93.

Krasnoyarskiy Rabochiy (1937). February, 10.

Krasnoyarsk Telegraph Agency of the Soviet Union. Reports on Pushkin in Khakas Language (1937), Krasnoyarskiy Rabochiy, January, 30.

N.Ch. (1937). An Interesting Exhibition. Krasnoyarskiy Rabochiy, January, 30.

Kobleva, T. Il'nitskaya, M. (1937) National Bard. Krasnoyarskiy Rabochiy, February, 10.

Soldiers and Officers of the Red Army read A.S. Pushkin // Krasnoyarskiy Rabochiy. 1937. February, 10.

Of the Greatest Russian Poet Pushkin's Death Centennial Anniversary Commemoration: the Decision of the USSR Central Executive Committee (1937). Pravda, February, 10.

2 Yesterday at the ceremonial meeting in Krasnoyarsk Pushkin Drama Theatre, Krasnoyarskiy Rabochiy, February, 11.

Yesterday in Bolshoi Theatre (1937). Pravda, February, 10.

14 Pushkin Days Abroad (1937). Pravda, February, 10.

Filin, M. (1990). Alexander Pushkin. Slovo. 6, 51.

The Glory of the Russian nation (1937). Pravda, February, 11.

Introduction by A.S. Bubnov. Pravda, February, 11.

Life and Work of A.S. Pushkin: the report of I.K. Luppola (1937). Pravda, February, 11.

The Dream of the Great Poet Comes True (1937). Pravda, February, 11.

Krasnoyarsk Region State Archive. fund 26, list 1, file 435, page 168, 263.

Kublitskiy, T., Stakkatov, A. (1936). The Day of Our City. Krasnoyarskiy Rabochiy, December, 24.

Krasnoyarskiy Rabochiy. (1937). March, 1.

23 Konovalov, N. (1937). To Work in a New Way. Krasnoyarskiy Rabochiy, March, 18.
} 


\title{
Пушкин и доктрина Сталина
}

\author{
А.С. Ильин \\ Красноярский государственный \\ аграрный университет \\ Россия, 660049, Красноярск, пр. Мира, 90
}

\begin{abstract}
Существует мнение о том, что связи с общественностью сформировались в США в 1930-х г2. и появились в России только в 1990-х наряду с рыночной экономикой и демократией. Это мнение правильно лишь частично. Действительно, как искусство и наука связи с общественностью сформировались в США. Однако строительство связей между властями и общественностью (правительственные отношения), как традиционно полагают, является коммуникативной функцией любого государственного органа. Общественное мероприятие (или кампания) часто используется в качестве сообщения, проходящего канал связи.

В 1930-х г2. в СССР Иосиф Сталин строил свой режим репрессий, обвиняя его противников в политических преступлениях. Но его режим нуждался в более твердой причине. Вот почему идеологи Сталина использовали столетнюю годовщину смерти Александра Пушкина. Во время кампании ознаменования доктрина мировой револючии была заменена доктриной строительства сочиализма в единственной стране, которая служила идеологическим фондом Красной империи.
\end{abstract}

Ключевые слова: связи с общественностью, коммуникации, А.С. Пушкин, доктрина идеологии.

Научная специальность: 07.00.00 - исторические науки. 